DOI: https://doi.org/10.11144/Javeriana.umed59-1.anem

\title{
Prevalence of Anemia and Interpretation of Hemoglobin Concentrations in Hospitalized Children from 6 Months to 5 Years of Age at the Hospital Universitario San Ignacio from January 1 to December 31, 2015
}

Prevalencia de anemia e interpretación de concentraciones de hemoglobina en niños hospitalizados de 6 meses a 5 años de edad en el Hospital Universitario San Ignacio desde el 1 de enero hasta el 31 de diciembre de 2015

\author{
Alexandra Castaño González ${ }^{\mathrm{a}}$ \\ Pontificia Universidad Javeriana, Colombia \\ Paula Carolina Guzmán Cruz \\ Pontificia Universidad Javeriana, Colombia \\ ORCID: http://orcid.org/0000-0002-6615-7161 \\ Diana Milena Bejarano Morales \\ Pontificia Universidad Javeriana, Colombia \\ Claudia Fernanda Idrobo Zapata \\ Pontificia Universidad Javeriana, Colombia
}

\begin{tabular}{ll}
\hline a Corresponding & author.
\end{tabular}

\begin{abstract}
Introduction: Anemia is common in children and is often not diagnosed. The aim of the study is to determine the prevalence and interpretation of hemoglobin levels $(\mathrm{Hb})$ in the population studied. Methods: All clinical histories of patients from 6 months to 5 years of age hospitalized and who underwent hemogram on HUSI, from January 1 to December 31, 2015, were evaluated. The population was characterized, the prevalence of anemia and the correct interpretation of Hb levels. Results: We analyzed 502 records. The prevalence of anemia was 54.3\% and in 197 (39\%) there was adequate interpretation. Conclusions: Anemia is frequent; the diagnosis should be optimized in children to improve the outcomes associated with the disease.

Keywords

anemia; iron-deficiency; hematocrit.
\end{abstract}

\section{RESUMEN}

Introducción: La anemia es frecuente en los niños y, con frecuencia, no se diagnostica. El objetivo del estudio es determinar su prevalencia y la interpretación de las concentraciones de hemoglobina $(\mathrm{Hb})$ de la población estudiada. Métodos: Se evaluaron todas las historias clínicas de pacientes de 6 meses a 5 años de edad hospitalizados y a quienes se les realizó hemograma (cuadro hemático), desde el 1 de enero hasta el 31 de diciembre de 2015. Se caracterizó la población, se determinó la prevalencia de anemia y la correcta interpretación de los niveles de $\mathrm{Hb}$. 
Resultados: Se analizaron 502 registros. La prevalencia de anemia fue del 54,3\% y en 197 (39\%) había adecuada interpretación. Conclusiones: La anemia es frecuente y se debe optimizar el diagnóstico en los niños para mejorar los desenlaces asociados con la enfermedad.

Palabras clave

anemia; anemia ferropénica; hematocrito.

\section{Introduction}

According to the World Health Organization, it is estimated that 1,620 million people in the world have anemia, which corresponds to $24.8 \%$ of the population (1). Preschool children are the population with the highest prevalence of anemia (47.4\%). In Colombia, it is a moderate public health problem and according to the National Survey on the Nutritional Situation 2010, the prevalence of anemia in children from 6 to 59 months was $27.5 \%$; from 5 to 12 years, $8.1 \%$, and from 13 to 17 years, $10.6 \%$. The population living in rural areas and belonging to levels 1 and 2 of the System for Selecting the Beneficiaries of Social Programs (Sisben) was the most affected (2).

Several studies have documented that iron deficiency and secondary anemia are associated with growth failure, delayed psychomotor development, behavioral alterations, cognitive dysfunction, poor school performance, immunological susceptibility, increased risk of infection and mortality $(2,3)$. In middle-income countries such as Colombia it is estimated that $0.2 \%$ of deaths in this population group are caused by anemia (2).

This is a disease characterized by a reduction in the concentration of hemoglobin $(\mathrm{Hb})$, below 2 standard deviations with respect to the normal population (4). The benchmark for the diagnosis of anemia is the measurement of $\mathrm{Hb}$. According to this value, anemia is classified as mild if the $\mathrm{Hb}$ is between 10 and $12.2 \mathrm{~g} / \mathrm{dl}$; as moderate if it is between 7 and $9.9 \mathrm{~g} / \mathrm{dl}$, and as severe if it is lower than $7 \mathrm{~g} / \mathrm{dl}(5,6)$.

It is important to bear in mind that the cutoff point for diagnosing anemia should be adjusted according to the height above sea level at which the patient resides, so in Bogota $1.3 \mathrm{~g} / \mathrm{dl}$ should be added to the cut-off point.
Although the amount of $\mathrm{Hb}$ can be modified by special situations, such as hemodilution or hemoconcentration, prematurity, among others, the operational definition is still based on specific concentrations of it. Therefore, in children from 6 months to 5 years of age in Bogotá, anemia is defined as $\mathrm{Hb}$ below $12.3 \mathrm{~g} / \mathrm{dl}(1)$.

The hemogram (complete blood count) is one of the most used diagnostic tests in pediatric clinical practice $(7,8,9,10)$. There is limited data on the prevalence of anemia in hospitalized children in Colombia and Latin America; therefore, as the complete blood count is a frequently used diagnostic aid, the pediatric hospitalization service and the benchmark for the diagnosis of anemia, it is relevant to determine whether the doctor correctly interprets $\mathrm{Hb}$ concentrations.

The main purpose of the study was to determine the prevalence of anemia in children from 6 months to 5 years of age who underwent a complete blood count during the hospitalization at the Hospital Universitario San Ignacio (HUSI) during 2015, and to evaluate the interpretation of the $\mathrm{Hb}$ concentrations by the doctor in the population described.

\section{Materials and Methods}

A retrospective, descriptive, observational study was carried out to evaluate all the clinical histories of patients from 6 months to 5 years of age hospitalized at the pediatric ward of HUSI who underwent a complete blood count from January 1 to December 31,2015 . The hemogram performed at the HUSI is a fifth generation hemogram.

An Excel $^{\circ}$ database was created with the variables of interest and two evaluators reviewed the medical records in order to minimize transcription errors in the database.

In the database, general sociodemographic variables were included: age, gender, type of social security, average length of stay, need for intensive care unit, as well as clinical variables, such as diagnosis, the presence or absence of anemia and its severity. Stata 10 software was used for the statistical analyzes. 


\section{Results}

We analyzed 502 records that corresponded to all the medical records of children from 6 months to 5 years of age hospitalized at the HUSI who underwent a complete blood count in 2015. The characteristics of the population studied are shown in Table 1.

Table 1

Population characteristics $(n=502)$

\begin{tabular}{|l|r|}
\hline Average age (months) & 24 \\
\hline Gender & 249 \\
\hline Female & 253 \\
\hline Male & \multicolumn{1}{|l|}{} \\
\hline Social Security & 445 \\
\hline Contributory Scheme & 57 \\
\hline Subsidized & 0 \\
\hline Associated & $\mathbf{2 2 . 8}$ \\
\hline Average length of hospital stay (days)
\end{tabular}

The prevalence of anemia in these subjects was $54.3 \%$ (273 records), and the physician's interpretation of $\mathrm{Hb}$ concentrations was adequate in $39 \%$ of the cases (197 records).

When the severity of the anemia was evaluated in the 273 registered cases, it was found that 242 had mild anemia (88.6\%) and 31 had moderate anemia (11.4\%). No patient with severe anemia was found. The diagnoses found were varied and they were grouped as shown in Table 2.

Table 2

Classification according to diagnoses $(n=502)$

\begin{tabular}{|l|r|}
\hline \multicolumn{1}{|c|}{ Diagnosis } & Diagnoses (n [\%]) \\
\hline Respiratory disorders & $265(52.7)$ \\
\hline Digestive disorders & $38(7.7)$ \\
\hline Genitourinary disorders & $34(6.8)$ \\
\hline Central nervous system disorders & $27(5.4)$ \\
\hline Soft tissue infections & $25(5.0)$ \\
\hline Hemato-oncological diseases & $23(4.5)$ \\
\hline Other infectious pathologies & $23(4.5)$ \\
\hline Scheduled surgeries & $20(4.0)$ \\
\hline Urgent surgical pathologies & $20(4.0)$ \\
\hline Other & $27(5.4)$ \\
\hline
\end{tabular}

The most frequent cause of hospitalization was respiratory diseases, such as bronchiolitis, pneumonia, asthma and other complicated upper respiratory infections. In the group of other infectious pathologies were osteoarticular infections, bacteremias, sepsis of unclear etiology, among others.

\section{Discussion and Conclusions}

The prevalence of anemia in the population studied was $54.3 \%$, which corresponds to twice the prevalence reported in the National Survey on the Nutritional Situation 2010 for this age group. Probably, this is related to the fact that hospitalized children have more frequently acute, chronic diseases and psychosocial conditions that are associated with anemia $(11,12,13)$.

The anemia found in most patients was mild (88.6\%) and there were no patients with severe anemia, which can be explained by the HUSI model of care, in which patients with severe anemia are managed in the emergency room or in the intensive care unit.

Of the blood counts performed, 39\% were adequately interpreted by the doctor, a value that could be explained because the adjustment of the $\mathrm{Hb}$ according to the height above sea level of the patient's place of residence has not been generalized in our institution. It is important to spread this procedure in the institution, to optimize the diagnosis of anemia. This can also be applied to other scenarios located more than 1,000 meters above sea level, where the adjustment for height is not carried out routinely.

Taking into account the results of the study, it is important to optimize the diagnosis of anemia in the pediatric population, in order to improve the outcomes associated with the disease.

\section{References}

1. 1. McLean E, Cogswell M, Egli I, et al. Worldwide prevalence of anaemia, WHO vitamin and mineral nutrition information system, 1993-2005. Public Health Nutr. 2009;12(4):444-54.

2. 2. Instituto Colombiano de Bienestar Familiar. Encuesta Nacional de la 
Situación Nutricional en Colombia, 2010. Bogotá. Profamilia; 2010.

3. 3. Powers J, Buchanan G: Diagnosis and management of iron deficiency anemia. Hematol Oncol Clin N Am. 2014;28:729-45.

4. 4. Brugnara C, Oski F, Nathan D. Diagnostic approach to the anemic patient. En: Nathan and Oski's hematology and oncology of infancy and childhood. 8th ed. Philadelphia: Elsevier; 2015. p. 293-307.

5. 5. Torrent Español M, Badell Serra I. Interpretación del hemograma y de las pruebas de coagulación. En: Curso de Actualización Pediatría 2012. Madrid: Exlibris; 2012. p. 203-16.

6. 6. Rondó PH, Condea A, Coelho Souza M, Sakuma A. Iron deficiency anaemia and blood lead concentrations in Brazilian children. Trans R Soc Trop Med Hyg. 2011;105(9):525-530. doi: https:// doi.org/10.1016/j.trstmh.2011.05.012

7. 7. Neuman MI, Shah SS, Shapiro, Hersh AJ. Emergency department management of childhood pneumonia in the United States prior to publication of national guidelines. Acad Emerg Med. 2013;20(3):240-6. doi: 10.1111/acem.12088

8. 8. Tarini BA, Garrison MM, Christakis DA. Institutional variation in ordering complete blood counts for children hospitalized with bronchiolitis. J Hosp Med. 2007 Mar;2(2):69-73.

9. 9. Macias CG, Mansch JM, Fisher ES, Riederer M, Piedra PA, Sullivan AF, et al. Variability in inpatient management of children hospitalized with bronchiolitis. Acad Pediatr. 2015;15(1):69-76.

10. 10. Florin TA, French B, Zorc JJ, Alpern ER, Shah SS. Variation in emergency department diagnostic testing and disposition outcomes in pneumonia. Pediatrics. 2013;132(2):237-44.

11. 11. Ramírez-Vélez R, Matínez-Torres J, Meneses-Echávez J. Prevalencia y factores sociodemográficos asociados a la deficiencia de ferritina en niños de Colombia, 2010. Rev Peru Med Exp Salud Publica. 2014;31(2):237-42.

12. 12. Simbauranga $R$, Kamugisha E, Hokororo A, Kidenya B, Makani J. Prevalence and factors associated with severe anaemia amongst under five children hospitalized at Bugando Medical Centre, Mwanza, Tanzania. BMC Hematol. 2015;15:13.

13. 13. Saba F, Poornima S, Rao Balaji P, Rao Varne S, Jayashree K. Anemia among hospitalized children at a multispecialty hospital, Bangalore (Karnataka), India. J Family Med Prim Care. 2014 Jan-Mar;3(1):48-53.

\section{Additional information}

How to cite: Castaño González A, Guzmán Cruz PC, Bejarano Morales DM, Idrobo Zapata CF. Prevalence of anemia and interpretation of hemoglobin concentrations in hospitalized children from 6 months to 5 years of age at the Hospital Universitario San Ignacio from January 1 to December 31, 2015. Univ Med. 2018;59(1):xx-xx. doi: https://doi.org/10.11144/ Javeriana.umed59-1.anem 